\title{
Determination of damaged leaf area and physiological responses of melon plants submitted to different infestation levels of Liriomyza sativae
}

\section{Ewerton M Costa; Rômulo Magno O Freitas; Paolo Augustus F Silva; Elton Lucio Araujo}

Universidade Federal Rural do Semi-Árido(UFERSA), Mossoró-RN, Brasil; ewertonmarinho10@hotmail.com; romulomagno_23@hotmail. com; paoloaugustus@hotmail.com; elton@ufersa.edu.br

\begin{abstract}
The leafminer Liriomyza sativae (Diptera: Agromyzidae) is one of the main pests of melon crop (Cucumis melo) in the Brazilian semiarid. The aims of this study were to determine the damaged leaf area and assess the physiological responses of melon plants submitted to different levels of infestation per larvae of $L$. sativae. The study was carried out in a greenhouse, using plants of melon of the cultivar Iracema (yellow melon). The design utilized was completely randomized, with five treatments [control (no infestation in the leaves) and four infestation levels $(1 ; 10 ; 20$ and 30 larvae per leaf)] and 10 replications (melon plants). Initially we evaluated the physiological aspects: photosynthetic rate $\left(\mu \mathrm{mol} \mathrm{CO} / \mathrm{m}^{2} / \mathrm{s}\right)$, stomatal conductance $\left(\mathrm{mol} \mathrm{H}_{2} \mathrm{O} / \mathrm{m}^{2} / \mathrm{s}\right)$ internal $\mathrm{CO}_{2}$ concentration $(\mu \mathrm{mol} \mathrm{CO} /$ $\mathrm{m}^{2}$ ) and leaf transpiration $\left(\mathrm{mmol} \mathrm{H}_{2} \mathrm{O} / \mathrm{m}^{2} / \mathrm{s}\right)$. After the measurements of physiological aspects, the evaluated leaves of each plant were cut close to the petiole and scanned individually with a measuring scale on the side, being the determination of the damaged leaf area performed with the aid of software for processing and analysis of images. The averages of damaged leaf area observed were of 1.2; $6.3 ; 19.6$ and $40.8 \mathrm{~cm}^{2}$ for infestations of $1 ; 10 ; 20$ and 30 larvae/ leaf respectively. In relation to the physiological aspects, the rate of photosynthesis, stomatal conductance and transpiration significantly decreased with the increase of leafminer larvae per leaf. The internal $\mathrm{CO}_{2}$ concentration increased with the increase in the number of larvae per leaf.
\end{abstract}

Keywords: Cucumis melo, leafminer, Agromyzidae, leaf damage, physiological aspects.

\begin{abstract}
RESUMO
Determinação da área foliar danificada e de respostas fisiológicas do meloeiro frente à infestação de Liriomyza sativae

A mosca-minadora [Liriomyza sativae (Diptera: Agromyzidae)] é uma das principais pragas do meloeiro (Cucumis melo) no semiárido brasileiro. Os objetivos do trabalho foram determinar a área foliar danificada e avaliar as respostas fisiológicas de plantas de meloeiro frente a diferentes níveis de infestação por larvas de L. sativae. O trabalho foi realizado em casa de vegetação, utilizando-se plantas de meloeiro cultivar Iracema (melão amarelo). O delineamento utilizado foi inteiramente casualizado, com cinco tratamentos [controle (folhas sem infestação) e quatro níveis de infestação (1; 10; 20 e 30 larvas por folha)] e 10 repetições (plantas de meloeiro). Inicialmente foram avaliados os aspectos fisiológicos: taxa fotossintética ( $\mu \mathrm{mol} \mathrm{CO}_{2} /$ $\left.\mathrm{m}^{2} / \mathrm{s}\right)$, condutância estomática $\left(\mathrm{mol} \mathrm{H}_{2} \mathrm{O} / \mathrm{m}^{2} / \mathrm{s}\right)$, concentração interna de $\mathrm{CO}_{2}\left(\mu \mathrm{mol} \mathrm{CO}_{2} / \mathrm{m}^{2}\right)$ e transpiração $\left(\mathrm{mmol} \mathrm{H}_{2} \mathrm{O} / \mathrm{m}^{2} / \mathrm{s}\right)$. Após as aferições dos aspectos fisiológicos, as folhas avaliadas de cada planta foram cortadas rente ao pecíolo e escaneadas individualmente junto com uma escala métrica ao lado, sendo a determinação da área foliar danificada realizada com auxílio de software para processamento e análise de imagens. Foram observadas médias de área foliar danificada de 1,$2 ; 6,3 ; 19,6$ e $40,8 \mathrm{~cm}^{2}$ para as infestações de $1 ; 10 ; 20$ e 30 larvas/folha, respectivamente. Em relação aos aspectos fisiológicos, a taxa fotossintética, a condutância estomática e a transpiração diminuíram significativamente com o aumento do número de larvas da mosca-minadora por folha. A concentração interna de $\mathrm{CO}_{2}$ aumentou com o incremento do número de larvas por folha.
\end{abstract}

Palavras-chave: Cucumis melo, mosca-minadora, Agromyzidae, danos foliares, aspectos fisiológicos.

Received on June 9, 2016; accepted on April 4, 2017

$\mathrm{L}$ eafminer Liriomyza sativae (Diptera: Agromyzidae) is one of the main pests of melon crop (Cucumis melo) in the Brazilian semiarid (Araujo et al., 2013). The larvae of this insect consumes the leaf mesophyll, decreasing photosynthetic capacity of the plants, which consequently promotes a reduction of accumulation of total soluble solids of the plants, decreasing the quality and affecting the market (Araujo et al., 2007; Guimarães et al., 2009).

Despite the knowledge about the damages caused by the attack of the leafminer, no information on the relation between the damage caused by the pest and physiological aspects in melon leaves can be found. Researches related to determination of physiological responses of the plants according to attack by insects may help, with other factors, as costs of phytosanitary treatment and production value, in order to determine the level of economic damage, and, consequently, the level of pest control, increasing integrated management system (Neves et al., 2006), since, the level of control is based on the number of insects per leaf, 
as it is in melon crop (Braga Sobrinho et al., 2007).

Due to the importance of species of the genus Liriomyza such as pests in ornamental and agricultural plant grown worldwide (Parrela, 1987; Murphy \& Lasalle, 1999), researches aiming to evaluate damaged leaf area and physiological aspects, especially photosynthetic rate, of plants infested with leafminer larvae had already been carried out in tomato (Solanum lycopersicum) (Johnson et al., 1983), celery (Apium graveolens) (Trumble et al., 1985), chrysanthemum (Chrysanthemum morifolium) (Parrela et al., 1985), lima bean (Phaseolus lunatus) (Martens \& Trumble, 1987), cherry tomato (Lycopersicon esculentum) (Lee et al., 2004), cucumber (Cucumis sativus) (Al-Khateeb \& Al-Jabr, 2006), potato (Solanum tuberosum) (Bueno et al., 2007) and beans (Phaseolus vulgaris) (Yildirim et al., 2010).

Thus, due to the lack of this kind of information for melon crop, researches in order to extend knowledge about the damage caused by the leafminer and subsidize the system for Integrated Pest Management (IPM) in the crop is fundamental. Therefore, the authors aimed, in this work, to quantify the damaged leaf area and evaluate the physiological responses of melon leaves exposed to different densities of $L$. sativae larvae per leaf.

\section{MATERIAL AND METHODS}

The experiment was carried out in a greenhouse, at Universidade Federal Rural do Semi-Árido (UFERSA), Mossoró, Rio Grande do Norte State, Brazil. Adults of $L$. sativae from the Laboratory of Applied Entomology of the UFERSA were used. The methodology used was recommended by Neves et al. (2006).

In order to obtain the plants, initially yellow melon seeds, cultivar Iracema (Sakata), which is one of the main cultivars grown in the region, were grown in polyethylene trays ( 162 cells), containing coconut fiber substrate
(Amifibra, Golden Mix). Twelve days after sowing, the seedlings were transplanted into 0.5 -kg-polyethylene pots, using as substrate sand and organic matter (Pole Fértil) in the ratio of 2:1. Seedlings were kept in the greenhouse and watered three times a day, until they reached vegetative stage with, at least, six definitive leaves. When the seedlings reached this vegetative stage, the plants were taken to the laboratory and submitted to leafminer infestation (adults at the age 24 to 72 hours), in three cages $(100 \times 100 \times 100 \mathrm{~cm})$ coated with anti-aphid screen, with an average of 50, 100 and 200 couples of leafminer in each cage, in order to make sure that the leaves would be infested in different levels. It was a 30-minute infestation period. Besides the insect couples mentioned, an individual infestation of 10 melon plants was carried out. One mating female (at the age between 24 and 72 hours) was used, considering that, to obtain only one larvae per leaf, the infestation was interrupted after the first puncture. After the infestation period, the plants were again taken to the greenhouse, and after 96 hours, necessary time for total larval development, the number of larvae per leaf was counted, with the aid of a magnifying glass (4x magnification), and plants were grouped according to the infestation level. The averages of infestations obtained were 1; 10; 20 and 30 larvae per leaf of melon plant.

The evaluation of the damaged leaf area and the physiological responses for each leaf was carried out after total larval development with the maximum consumption of plant tissue. Physiological aspects were evaluated using a portable photosynthesis meter system, model LI-6400 (LI-COR Biosciences), calibrated with $\mathrm{CO}_{2}$ levels set at $400 \mu \mathrm{moles} / \mathrm{m}^{2} / \mathrm{s}$ and light intensity of $1500 \mu \mathrm{moles} / \mathrm{m}^{2} / \mathrm{s}$. The measurements were carried out in $6 \mathrm{~cm}^{2}$, maximum area of the meter, measuring the most expanded leaf of the plant. The average leaf area of the evaluated leaves was $90.8 \pm 1.9 \mathrm{~cm}^{2}$. The physiological aspects evaluated were photosynthetic rate $(\mu \mathrm{mol} \mathrm{CO} /$ $\left.\mathrm{m}^{2} / \mathrm{s}\right)$, stomatal conductance $\left(\mathrm{mol} \mathrm{H}_{2} \mathrm{O} /\right.$ $\left.\mathrm{m}^{2} / \mathrm{s}\right)$, internal $\mathrm{CO} 2$ concentration $(\mu \mathrm{mol}$
$\mathrm{CO}_{2} / \mathrm{m}^{2} / \mathrm{s}$ ) and transpiration ( $\mathrm{mmol}$ $\mathrm{H}_{2} \mathrm{O} / \mathrm{m}^{2} / \mathrm{s}$ ). All the measurements were carried out during the morning, between 8:00 a.m. and 11:00 a.m., under average air temperature $37^{\circ} \mathrm{C}$ and relative humidity of $72 \%$ (averages obtained with a thermohygrometer).

In order to determine the damaged leaf area, after measuring physiological aspects, the leaves of each plant were cut near the petiole and scanned individually with a metric scale. Then, using a software for processing and analysis of images ImageJ (Rasband, 1997), the damaged leaf area was determined, in $\mathrm{cm}^{2}$, for each level of leafminer infestation in melon leaves.

The experimental design was completely randomized, with five treatments \{control (non-infested leaves) $\}$ and four levels of infestation (1; 10; 20 and 30 larvae/leaf) and 10 replicates (melon plants). The experimental unit consisted of one leaf. The data obtained were submitted to variance analysis, and afterwards, the regression analysis was carried out using the statistical program R ( R Development Core Team, 2011).

\section{RESULTS AND DISCUSSION}

The damaged leaf area increased significantly in relation to the increase of number of larvae per leaf. For the smallest infestation (1 larva/leaf), an average damaged area of $1.2 \mathrm{~cm}^{2} /$ leaf was observed, which corresponded to $1.5 \%$ of the total leaf area. In major infestation (30 larvae/leaf), the average injury caused was of $40.8 \mathrm{~cm}^{2}$, representing $44.0 \%$ of the total leaf area. The infestations of 10 and 20 larvae/ leaf caused injuries with average sizes of $6.3 \mathrm{~cm}^{2}$ and $19.6 \mathrm{~cm}^{2}$, respectively (Figure 1).

The melon leaf injury caused by leafminer larvae affects the productivity and the quality of the fruits (Araujo et al., 2007; Guimarães et al., 2009); this fact has motivated researches on, as an example, the evaluation of resistance of melon genotypes to this pest attack (Lima, 2012; Nunes et al., 2013). 
However, little information on damaged leaf area related to injury caused by the leafminer larvae in melon can be found. Nevertheless, the increase of the damaged leaf area in relation to the increase of leafminer larval density per leaf, was already reported for other economically important crops. Johnson et al. (1983) verified that infestations from 1 to 8 larvae of $L$. sativae per tomato leaflet caused injuries of 0.25 $\mathrm{cm}^{2}$ and $2.09 \mathrm{~cm}^{2}$, respectively. Yildirim et al. (2010) observed reductions of $12.21 \%, 31.31 \%$ and $98.38 \%$ on the leaf area of common bean $P$. vulgaris for infestations from 1 to 5,6 to 15 and 16 to 25 larvae of $L$. trifolii per leaf, respectively. Based on the results shown by other authors and the results obtained in this work, we can state that the size of the injury caused by leafminer larvae varies according to the plant species attacked, especially due to the size of the leaves.

In relation to physiological responses, all the evaluated aspects were influenced significantly by the number of leafminer larvae per leaf. The photosynthetic rate of melon leaves decreased with the increase in number of larvae; we obtained average values which ranged from $18.8 \mu \mathrm{mol} \mathrm{CO} / \mathrm{m}^{2} / \mathrm{s}$, observed on leaves without infestation, to $9.3 \mu \mathrm{mol} \mathrm{CO} / \mathrm{m}^{2} / \mathrm{s}$ on leaves with the highest number of larvae (30 larvae/ leaf), which represented a reduction of $50.7 \%$ in photosynthetic rate (Figure 2).

The reduction in photosynthetic rate verified from the lowest level of leafminer infestation (1 larva/leaf) is due to the fact that the pest larvae consume the leaf mesophyll which, according to Taiz \& Zeiger (2009) is the most active photosynthetic tissue in the upper plant. Reductions in photosynthetic capacity due to the attack of Liriomyza larvae were reported in tomato leaves (Johnson et al., 1983), celery (Trumble et al., 1985), chrysanthemum (Parrela et al., 1985), lima bean (Martens \& Trumble, 1987), and cucumber (AlKhateeb \& Al-Jabr, 2006). Besides these researches, Yildirim et al. (2010) observed a significant decreasing in chlorophyll content in relation to the density of larvae of L. trifolii on bean leaves, which also implies reduction of

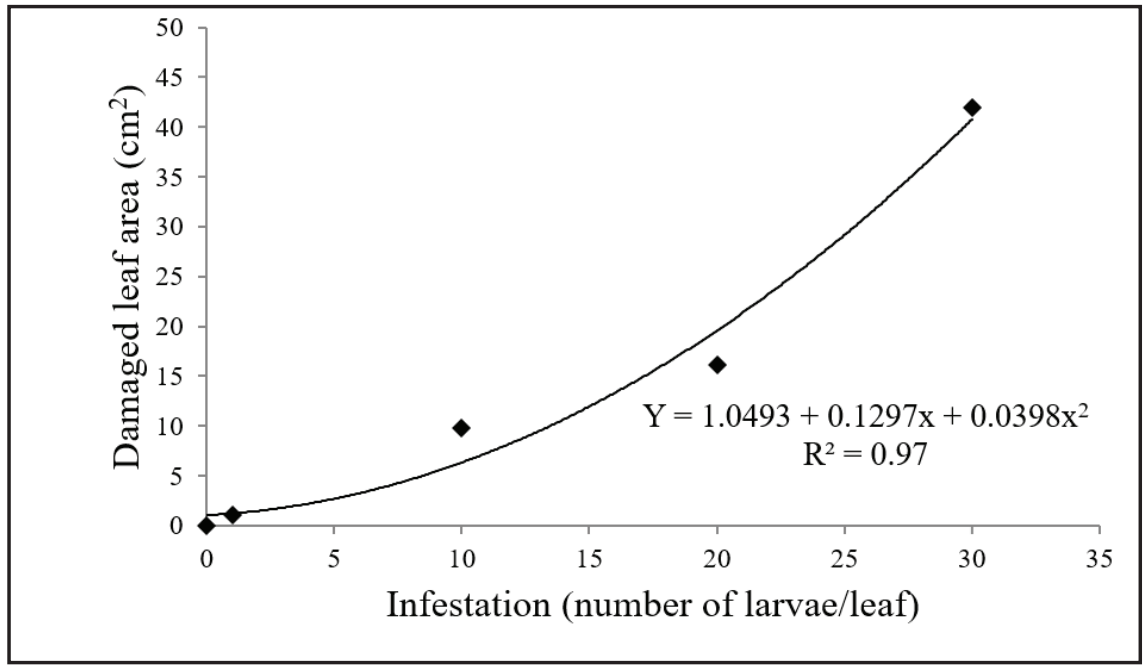

Figure 1. Damaged leaf area $\left(\mathrm{cm}^{2}\right)$ in melon plants, submitted to different levels of infestation (number of larvae/leaf) of the leafminer Liriomyza sativae. Mossoró, UFERSA, 2016.

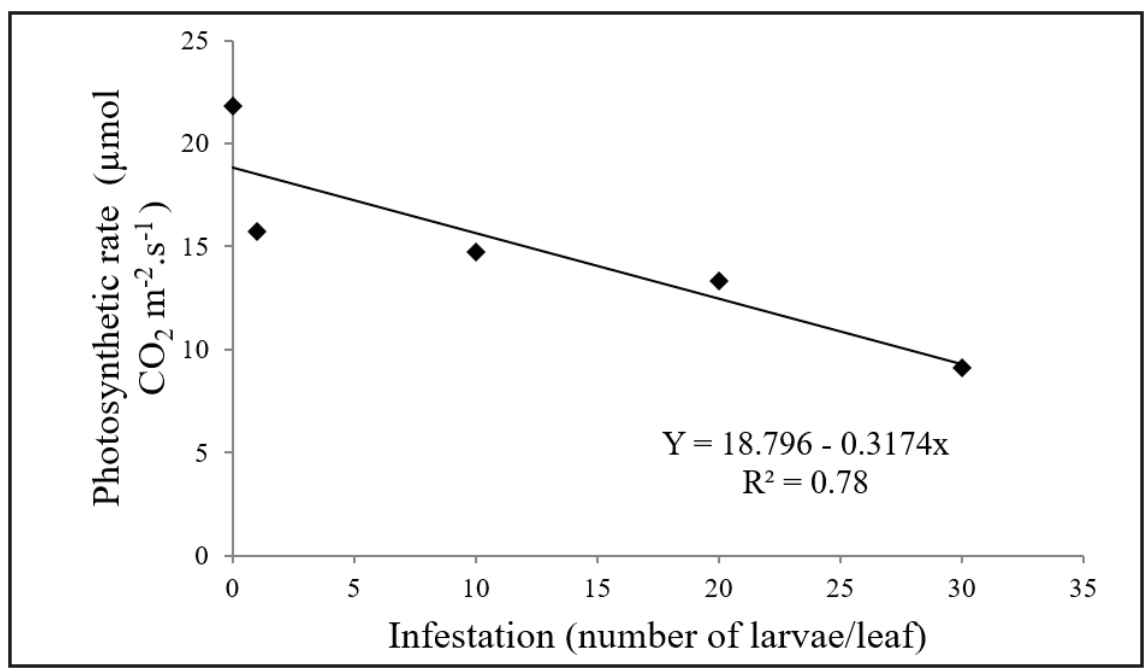

Figure 2. Photosynthetic rate on melon leaf, submitted to different levels of infestation (number of larvae/leaf) of the leafminer Liriomyza sativae. Mossoró, UFERSA, 2016.

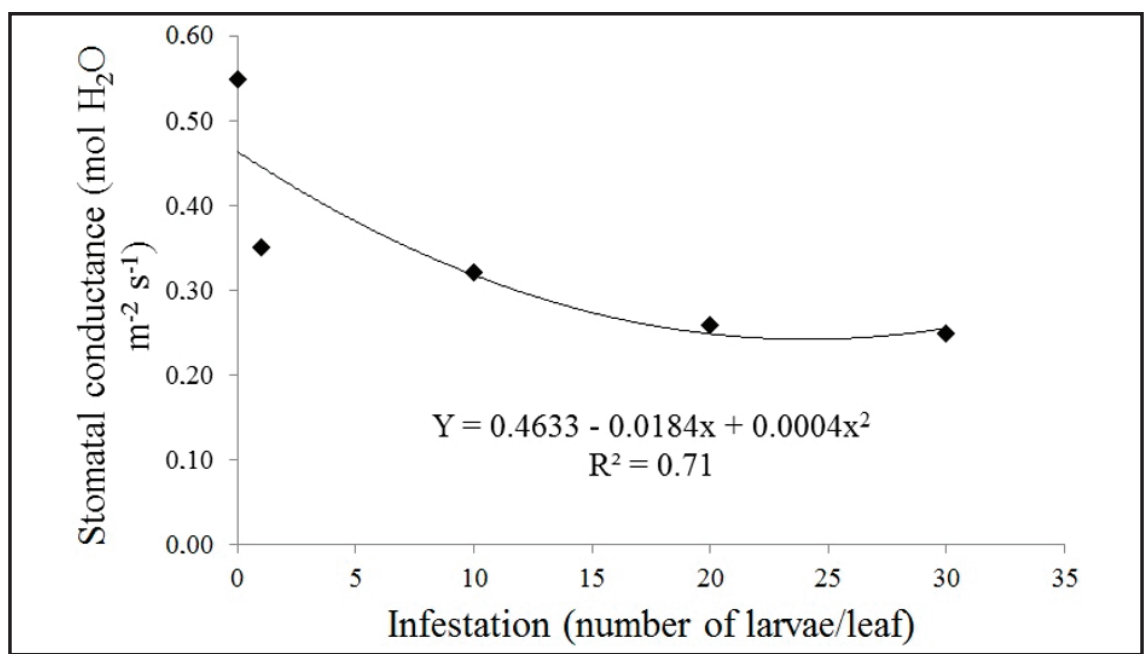

Figure 3. Stomatal conductance on melon leaf, submitted to different levels of infestation (number of larvae/leaf) of the leafminer Liriomyza sativae. Mossoró, UFERSA, 2016. 
photosynthetic capacity.

The injury resulting from the larval feeding process also decreased significantly the stomatal conductance and transpiration, also increased the internal $\mathrm{CO}_{2}$ concentration in melon leaves. The average value of the stomatal conductance on the non-infested leaves was $0.46 \mathrm{~mol} \mathrm{H}_{2} \mathrm{O} / \mathrm{m}^{2} / \mathrm{s}$, whereas in leaves with the highest density of larvae (30 larvae/leaf) was $0.27 \mathrm{~mol} \mathrm{H}_{2} \mathrm{O} / \mathrm{m}^{2} / \mathrm{s}$, which corresponded to a reduction of $41.4 \%$ (Figure 3). For transpiration, we observed a range from $6.5 \mathrm{mmol}$ $\mathrm{H}_{2} \mathrm{O} / \mathrm{m}^{2} / \mathrm{s}$ to $5.1 \mathrm{mmol} \mathrm{H}_{2} \mathrm{O} / \mathrm{m}^{2} / \mathrm{s}$ among the non-infested leaves and the leaves showing the highest density of larvae, respectively (Figure 4). On the other hand, the internal $\mathrm{CO}_{2}$ concentration in the leaves increased according to increasing infestation, being observed a concentration of $291.4 \mu \mathrm{mol} \mathrm{CO} /$ $\mathrm{m}^{2}$ in leaves with 30 larvae, which corresponded to an increase of $7.5 \%$ in relation to the internal $\mathrm{CO}_{2}$ concentration observed on non-infested leaves (269.6 $\mu \mathrm{mol} \mathrm{CO} / \mathrm{m}^{2}$ ) (Figure 5).

Stomatal conductance, transpiration and internal $\mathrm{CO}_{2}$ concentration are closely related to the photosynthetic

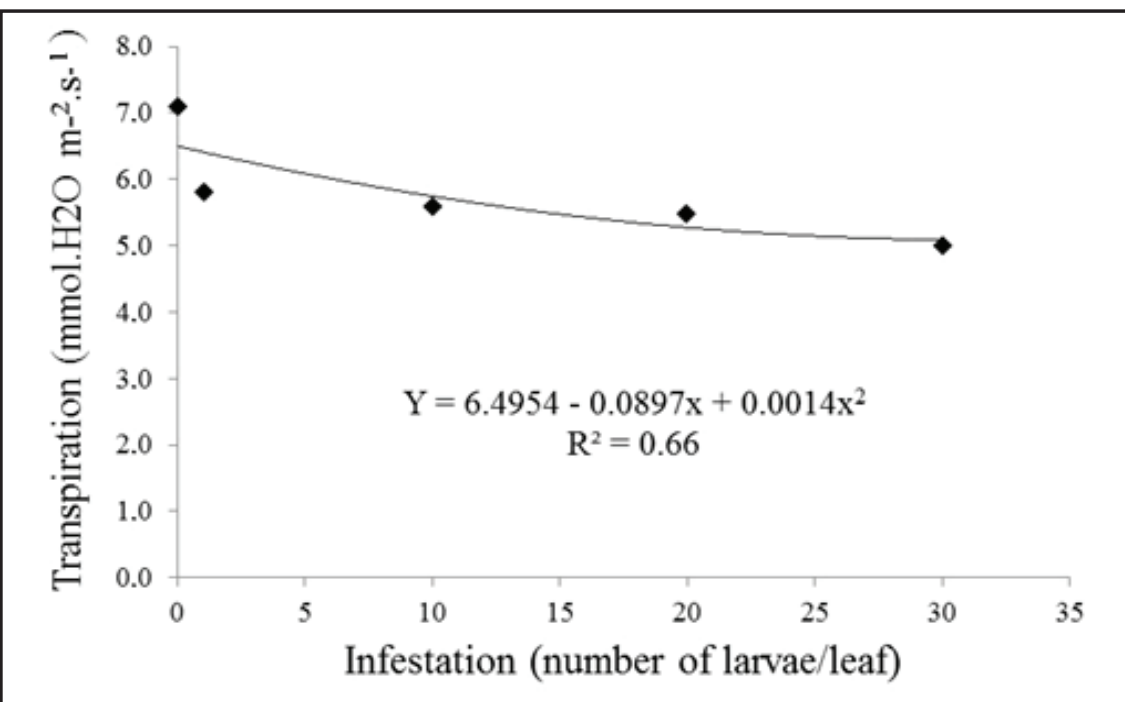

Figure 4. Transpiration of melon leaf, submitted to different levels of infestation (number of larvae/leaf) of the leafminer Liriomyza sativae. Mossoró, UFERSA, 2016.

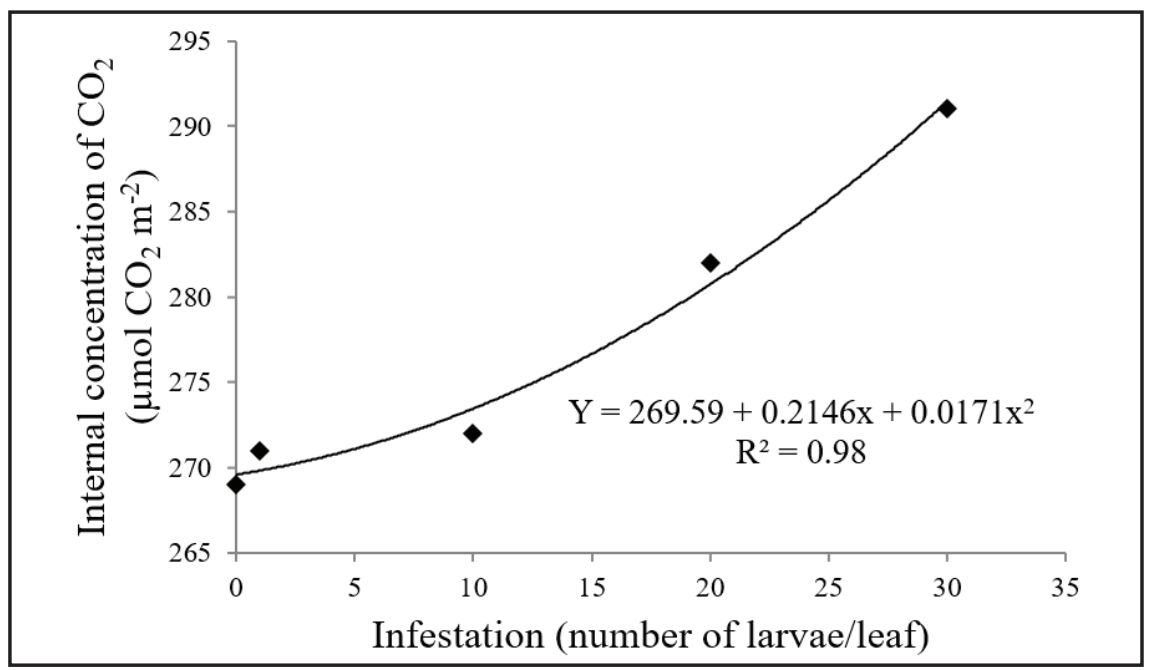

Figure 5. Internal concentration of $\mathrm{CO}_{2}$ of melon leaf, submitted to different levels of infestation (number of larvae/leaf) of the leafminer Liriomyza sativae. Mossoró, UFERSA, 2016. process, considering that interferences in the normal functioning of these processes can negatively affect the plants (Pimentel, 2004; Taiz \& Zeiger, 2009). The reduction in stomatal conductance decrease transpiration and it is a barrier to the absorption of $\mathrm{CO}_{2}$, which causes a decreasing in photosynthetic rate (Pearcy \& Pftisch, 1991; Pimentel, 2004; Taiz \& Zeiger, 2009). Similar variations in the mentioned physiological aspects were observed in other crops under leafminer infestation. Johnson et al. (1983) also verified, in tomato plants, that with an increase of infestation by L. sativae larvae, a reduction in stomatal conductance in leaves is noticed. In celery leaves, Trumble et al. (1985) observed that infestation by L. trifolii reduced stomatal conductance and transpiration. In cucumber crop AlKhateeb \& Al-Jabrr (2006) verified an increase in internal $\mathrm{CO}_{2}$ concentration with an increase in L. trifolii intensity of infestation.

This study presents the first information on damaged leaf area and physiological responses of melon leaves, cultivar Iracema, infested with $L$. sativae larvae. The results obtained in this study show damages caused by leafminer larvae, in different larval densities, affect physiological processes (photosynthetic rate, stomatal conductance, transpiration and internal $\mathrm{CO}_{2}$ concentration) of melon leaves, considering that change in these processes, one of the main responsible processes for reducing the productivity and quality of fruits, especially due to the lowest accumulation of total soluble solids. Moreover, this information may be important in order to develop new researches which aim to correlate infestation levels, reduction of photosynthetic capacity and contents of total soluble solids, under field conditions, aiming to establish more appropriate levels of control for leafminer in melon crop.

\section{ACKNOWLEDGEMENT}

The CAPES that granted doctoral scholarship to the first author. 


\section{REFERENCES}

AL-KHATEEB, SA; AL-JABR, AM. 2006. Effect of leafminer Liriomyza trifolii (Burgess) (Diptera: Agromyzidae) on gas exchance capacity of cucumber, Cucumis sativus L. grown under greenhouse conditions. Acta Horticulturae 710: 423-428.

ARAUJO, EL; FERNANDES, DRR; GEREMIAS, LD; NETTO, ACM; FILGUEIRA, MA. 2007. Mosca minadora associada à cultura do meloeiro no Semi-Árido do Rio Grande do Norte. Revista Caatinga 20: 210-212.

ARAUJO, EL; NOGUEIRA, CHF; MENEZES NETTO, AC; BEZERRA, CES. 2013. Biological aspects of the leafminer Liriomyza sativae (Diptera: Agromyzidae) on melon (Cucumis melo L.). Ciência Rural 43: 579-582.

BRAGA SOBRINHO, R; GUIMARÃES, JA; ARAUJO, EL; ASSIS, JS; MOREIRA, MAB; MACEDO, LPM; MESQUITA, ALM. 2007. Monitoramento de pragas na produção integrada do meloeiro. $2^{\mathrm{a}}$ ed. Embrapa (Documentos, 69) 22p.

BUENO, AF; ZECHMANN, B; HOBACK, WW; BUENO, RCOF; FERNANDES, OA. 2007. Serpentine leafminer (Liriomyza trifolii) on potato (Solanum tuberosum): field observations and plant photosynthetic responses to injury. Ciência Rural 37: 15101517.

GUIMARÃES, JA; FILHO, MM; OLIVEIRA, VR; LIZ, RS; ARAUJO, E L. 2009. Biologia e manejo de mosca-minadora no meloeiro.
Embrapa, Comunicação Cientifica.

JOHNSON, MW; WELTER, SC; TOSCANO, NC; TING, IP; TRUMBLE, JT. 1983. Reduction of tomato leaflet photosynthesis rates by mining activity of Liriomyza sativae (Diptera: Agromyzidae). Journal of Economic Entomology 76: 1061-1063.

LEE, DH; PARK, JJ; CHO, K. 2004. Characterization of leaf mining damage of Liriomyza trifolii (Diptera: Agromyzidae) in cherry-tomato greenhouse. Journal of AsiaPacific Entomology 7: 201-205.

LIMA, MAA. 2012. Resistência de genótipos de meloeiro à mosca-minadora Liriomyza sativae (Blanchard, 1938) (Diptera: Agromyzidae). Piracicaba: ESALQ. 120p (Tese doutorado).

MARTENS, B; TRUMBLE, JT. 1987. Structural and photosynthetic compensation for leafminer (Diptera: Agromyzidae) injury in lima beans. Environmental Entomology 16: 374-378.

MURPHY, ST; LASALLE, J. 1999. Balancing biological control strategies in the IPM of new world invasive Liriomyza leafminers in field vegetable crops. Biocontrol News and Information 20: 91-104.

NEVES, AD; OLIVEIRA, RF; PARRA, JRP. 2006. A new concept for insect damage evaluation based on plant physiological variables. Anais da Academia Brasileira de Ciências 78: 821-835.

NUNES, GHS; MEDEIROS, AC; ARAUJO, EL; NOGUEIRA, CHF; SOMBRA, KDS. 2013. Resistência de acessos de meloeiro à mosca-minadora Liriomyza spp. (Diptera: Agromyzidae). Revista Brasileira de Fruticultura 35: 746-754.
PARRELA, MP; JONES, VP; YOUNGMAN, RR. 1985. Effect of leaf mining and leaf stippling of Liriomyza spp. on photosynthetic rates of Chrysanthemum. Annals Entomology Society American 78: 90-93.

PARRELA, MP. 1987. Biology of Liriomyza. Annual Review of Entomology 32: 201-224.

PEARCY, RW; PFITSCH, WA. 1991. Influence of Adeno caulon bicolor plants occurring in contrasting forest understory microsites. Oecologia 86: 457-462.

PIMENTEL, CA. 2004. Relação da planta com a água. $1^{a}$ ed. Seropédica: Edur. 191p.

R DEVELOPMENT CORE TEAM. 2011. R: A language and environment for statistical computing. R Foundation for Statistical Computing, Vienna, Austria. ISBN 3-90005107-0. Available from: $<$ http://www.r-project. org/>. Accessed on Mai, 05, 2015.

RASBAND, WS. 1997. Image J: Image Processing and Analysis in Java. Disponivel em: <http:// rsb.info.nih.gov/ij/>, acessado em 17 jan. 2016.

TAIZ, L; ZEIGER, E. 2009. Fisiologia Vegetal. 4.ed. Porto Alegre: Artmed. 820 p.

TRUMBLE, JT; TING, IP; BATES, L. 1985. Analysis of physiological, growth, and yield responses of celery to Liriomyza trifolii. Entomologia Experimentalis et Applicata 38: 15-21.

YILDIRIM, EM; ÜNAY, A; CIVELEK, HS. 2010. The effect of Liriomyza trifolii (Burgess) (Diptera: Agromyzidae) on some leaf characteristics of bean (Phaseolus vulgaris $\mathrm{L}$.). Journal of Food, Agriculture \& Environment 8: 839-841. 